\title{
Urotensin II-induced signaling involved in proliferation of vascular smooth muscle cells
}

This article was published in the following Dove Press journal:

Vascular Health and Risk Management

10 August 2010

Number of times this article has been viewed

\section{Myriam Iglewski \\ Stephen R Grant}

Department of Integrative Physiology, University of North Texas Health Science Center, Fort Worth,

Texas, USA
Correspondence: Stephen R Grant Department of Integrative Physiology, UNT Health Science Center, 3500 Camp Bowie Boulevard, Fort Worth, Texas 76107, USA

Tel +l 8I7 7352569

Email sgrant@hsc.unt.edu

\begin{abstract}
The urotensin II receptor, bound by the ligand urotensin II, generates second messengers, ie, inositol triphosphate and diacylglycerol, which stimulate the subsequent release of calcium $\left(\mathrm{Ca}^{2+}\right)$ in vascular smooth muscle cells. $\mathrm{Ca}^{2+}$ influx leads to the activation of $\mathrm{Ca}^{2+}$-dependent kinases ( $\mathrm{CaMK}$ ) via calmodulin binding, resulting in cellular proliferation. We hypothesize that urotensin II signaling in pulmonary arterial vascular smooth muscle cells (Pac1) and primary aortic vascular smooth muscle cells (PAVSMC) results in phosphorylation of $\mathrm{Ca}^{2+} /$ calmodulin-dependent kinases leading to cellular proliferation. Exposure of Pac1 cultures to urotensin II increased intracellular $\mathrm{Ca}^{2+}$, subsequently activating $\mathrm{Ca}^{2+} /$ calmodulin-dependent kinase kinase (CaMKK), and $\mathrm{Ca}^{2+} /$ calmodulin-dependent kinase Type I (CaMKI), extracellular signal-regulated kinase (ERK 1/2), and protein kinase D. Treatment of Pac1 and PAVSMC with urotensin II increased proliferation as measured by ${ }^{3} \mathrm{H}$-thymidine uptake. The urotensin II-induced increase in ${ }^{3} \mathrm{H}$-thymidine incorporation was inhibited by a CaMKK inhibitor. Taken together, our results demonstrate that urotensin II stimulation of smooth muscle cells leads to $\mathrm{a} \mathrm{Ca}^{2+} /$ calmodulin-dependent kinase-mediated increase in cellular proliferation.
\end{abstract}

Keywords: urotensin II receptor, CaMKI, hypertrophy, CaMKK, protein kinase D

\section{Introduction}

Hypertrophy, inflammation, and proliferation of vascular cells are major contributors to diseases such as atherosclerosis, arteriosclerosis, and hypertension. ${ }^{1}$ The combined effects of these major contributors are increases in cell size, migration of immune cells, and abnormal cell growth in affected regions of the vessel. ${ }^{2}$ Changes in vessel structure due to vascular remodeling result in narrowing of the vessel wall and arterial stiffness. $^{2}$ Contraction and relaxation of vascular smooth muscle cells are regulated by biologically active mediators which are synthesized and secreted to modulate vascular tone..$^{1}$ Many of these same mediators also play a pathologic role, such as urotensin II, which can induce abnormal cellular proliferation during disease-related vascular remodeling. ${ }^{1}$

Urotensin II is similar to somatostatin in both structure and function. Urotensin II is an undecapeptide cleaved from a precursor molecule that stimulates potent vasoconstriction and vascular smooth muscle cell proliferation. ${ }^{3,4}$ Under nonpathologic conditions, urotensin II influences vascular smooth muscle contraction. ${ }^{5}$ However, under pathologic conditions, urotensin II promotes cellular migration, and modulates large blood vessels, as shown in studies conducted in human aortic smooth muscle cells. ${ }^{6}$

Urotensin II is recognized by the orphan G-protein coupled GPR-14, now identified as the urotensin II receptor, resulting in generation of the second messengers, 
inositol triphosphate and diacylglycerol. ${ }^{7,8}$ These second messengers trigger the release of $\mathrm{Ca}^{2+}$ from the sarcoplasmic reticulum. ${ }^{9}$ The urotensin II receptor is expressed in many tissues, including vascular smooth muscle, although the precise mechanisms activated downstream of the urotensin II receptor in vascular smooth muscle cells are largely unknown. ${ }^{10}$ Studies of other Gq-coupled receptors have shown that stimulation induces intracellular $\mathrm{Ca}^{2+}$ influx and binding of $\mathrm{Ca}^{2+}$ to calmodulin. ${ }^{11,12}$ Activated calmodulin subsequently binds to and stimulates calmodulin-dependent kinases (CaMK), such as $\mathrm{Ca}^{2+} /$ calmodulin-dependent kinase kinase $(\mathrm{CaMKK}) \cdot{ }^{13}$ Activation of CaMK members can lead to $\mathrm{Ca}^{2+}$-dependent activation of other protein kinases, such as extracellular signal-regulated kinase (ERK) and protein kinase D (PKD). ${ }^{14-16}$

ERK phosphorylation is required for proliferation of various cell types and cell lines. ${ }^{17,18}$ Vascular remodeling, hypertrophy, and proliferative responses are believed to be the result of urotensin II receptor overstimulation. ${ }^{19,20}$ Studies in thoracic aortic cells demonstrated that urotensin II receptor signaling stimulates the phosphorylation of ERK. ${ }^{5,21}$ In addition to ERK activation, intracellular $\mathrm{Ca}^{2+}$ influx can also modulate the activity of PKD. ${ }^{14}$ Vasoactive agents, such as endothelin-1, that bind Gq-coupled receptors, have been demonstrated to mediating PKD phosphorylation in various cell types. ${ }^{22}$ Here, we show that urotensin II induces intracellular $\mathrm{Ca}^{2+}$ release which stimulates CaMKI phosphorylation in Pac1. Moreover, we demonstrate that urotensin II receptor stimulation leads to CaMK-dependent phosphorylation of ERK and PKD. We go on to reveal that the acute application of urotensin II results in cellular proliferation, which can be blocked by inhibition of CaMKK. Consistent with our hypothesis, we have found that urotensin II-induced CaMKI, ERK, and PKD phosphorylation are also blocked by inhibition of CaMKK in vascular smooth muscle cells. These observations potentially indicate that urotensin II-induced signaling triggers proliferation and may contribute to hypertrophic pathologic conditions.

\section{Materials and methods}

\section{Cell culture}

Rat pulmonary arterial smooth muscle cells (Pac1) were cultured according to the method described by Rothman A et al. ${ }^{11}$ In brief, rat Pac1 were cultured in medium 199 (Invitrogen, Carlsbad, CA) supplemented with 10\% fetal bovine serum with gentamicin (Fisher Scientific, Pittsburgh, PA). The cells were carried only through passages $3-15$.

\section{Primary aortic smooth muscle cells}

Rat aortas were isolated from three-month-old SpragueDawley rats according to an established protocol. ${ }^{23}$ The aortas were incubated for five minutes in $10 \%$ fetal bovine serum and 199 medium, then incubated at $37^{\circ} \mathrm{C}$ for 30 minutes in Hanks Balanced Salt Solution (Invitrogen-GIBCO, Carlsbad, CA) with $70 \mathrm{U} / \mathrm{mL}$ of collagenase (Millipore-Worthington Biochemical Company, Billerica, MA). Adventitias were stripped from the aortic tissue with watchmaker forceps and discarded. Aortas were digested in Hanks Balanced Salt Solution with collagenase $70 \mathrm{U} / \mathrm{mL}$ and elastase $40 \mathrm{U} / \mathrm{mL}$ (Sigma Aldrich, St Louis, MO). Aortas were gently agitated at $37^{\circ} \mathrm{C}$ for 90 minutes. The aortic solution was passed through a strainer with a $70 \mu \mathrm{m}$ pore size, and centrifuged at 900 rpm for five minutes. Cellular suspensions were dispersed by pipetting the suspensions up and down. Cells were then plated in six-well plates containing $10 \%$ fetal bovine serum in 199 medium.

\section{Calcium imaging}

Pac1 $(1 \times 105$ cells $/ \mathrm{mL})$ were grown on coverslips at $70 \%-80 \%$ confluency, and then bathed in Hanks Balanced Salt Solution (containing $\mathrm{NaCl} 0.137 \mathrm{M}, \mathrm{KCl} 5.4 \mathrm{mM}$, $\mathrm{Na}_{2} \mathrm{PO}_{4} 0.25 \mathrm{mM}, \mathrm{KH}_{2} \mathrm{PO}_{4} 0.44 \mathrm{mM}, \mathrm{MgSO}_{4} 1.0 \mathrm{mM}$, $\mathrm{NaHCO}_{3} 4.2 \mathrm{mM}$ ) with and without $\mathrm{Ca}^{2+}$ for measuring intracellular $\mathrm{Ca}^{2+}$. Detection of intracellular $\mathrm{Ca}^{2+}$ was quantified using a ratiometric technique recognized by Fura-2-AM (Invitrogen) involving excitation at $340 \mathrm{~nm}$ and $380 \mathrm{~nm}$ with emission at $510 \mathrm{~nm}$ according to Prasanne et al. ${ }^{24}$ A Nikon Diaphot microscope using Metafluor software (Universal Imaging, West Chester, PA) was used to measure intracellular $\mathrm{Ca}^{2+}$. Concentration (nM) of intracellular $\mathrm{Ca}^{2+}$ was calculated using the Grynkeiwicz equation. Ethylenediamine tetraacetic acid $0.5 \mu \mathrm{M}$, a membrane-impermeable chemical chelating agent that binds $\mathrm{Ca}^{2+}$, was used to reverse the elevated levels of $\mathrm{Ca}^{2+}$. BAPTA-AM (1, 2-bis(2-aminophenoxy)- ethane$\mathrm{N}, \mathrm{N}, \mathrm{N}$ ', N'-tetra-acetic acid) $10 \mu \mathrm{M}$ (Invitrogen) was also used as a $\mathrm{Ca}^{2+}$ chemical chelating agent. BAPTA-AM, a membrane-permeable compound, also reverses the elevated levels of intracellular $\mathrm{Ca}^{2+}$.

\section{Immunostaining}

Pac1 and PAVSMC were cultured $(1 \times 105$ cells $/ \mathrm{mL})$ on glass coverslips and washed twice with phosphate-buffered solution and fixed for 15 minutes with 4\% paraformaldehyde at room temperature. Cells were blocked for one hour in blocking solution $3.0 \%$ bovine serum albumin in phosphate-buffered solution), and then incubated for 
one hour in primary antibody smooth muscle cell-specific antimyosin IgG (Biomedical Technologies Incorporated, Stoughton, MA) diluted 1:200 or anti-GPR14R (antibody for the urotensin II receptor, Alpha Diagnostic International Inc., Woodlake Center, TX) antibody 1:200 with blocking solution. The secondary fluorescent labeling was incubated with cells using 1:500 Alexa 488 goat/antirabbit (Molecular Probes- Invitrogen, Eugene, OR) in blocking solution. The cells were washed three times with phosphate-buffered solution. Coverslips were mounted on slides with Pro-Long Gold Anti-Fade and DAPI (Invitrogen). A DP70 Olympus digital camera and AX70 fluorescent microscope was used to visualize stained cells $(40 \times$ objective $)$.

\section{${ }^{3} \mathrm{H}$-thymidine incorporation assay}

Pac 1 and PAVSMC were seeded $(8 \times 104$ cells $/ \mathrm{mL})$ in RPMI (Invitrogen) medium containing 10\% fetal bovine serum. After $70 \%$ confluency, cells were washed with phosphatebuffered solution and serum starved in serum-free media to induce G1 arrest. Cells were serum-starved for 24 and 48 hours and were incubated in serum-free RPMI media or isotonic artificial CSF (ACSF, $142 \mathrm{mM} \mathrm{NaCl}, 5 \mathrm{mM} \mathrm{KCl}$, $10 \mathrm{mM}$ glucose, $1.3 \mathrm{mM} \mathrm{Mg}^{2+} 10 \mathrm{mM}$ HEPES, and in the presence or absence of $3.1 \mathrm{mM} \mathrm{Ca}{ }^{2+}$ containing $1 \mu \mathrm{Ci} / \mathrm{mL}$ of ${ }^{3} \mathrm{H}$-thymidine, specific activity $48.0 \mathrm{Ci} / \mathrm{mmol}$ (GE-Healthcare-Amersham Pharmacia, Piscataway, NJ) for four hours in the $\mathrm{CO}_{2}$ incubator at $37^{\circ} \mathrm{C}$ in the presence and absence of urotensin II $100 \mathrm{nM}$ (Sigma Aldrich) and STO609 $250 \mathrm{nM}$ (Sigma Aldrich). After the four-hour incubation period, cells were washed with phosphate-buffered solution. Cells were precipitated with $15 \%$ trichloroacetic acid and incubated overnight at $4^{\circ} \mathrm{C}$. Cells were then lysed with 1 Normal $\mathrm{NaOH}$ and were incubated for 30 minutes at room temperature. Cell lysates were transferred to tubes containing scintillation fluid for analysis using a Beckman 1539 scintillation counter. Proliferation was measured by incorporation of ${ }^{3} \mathrm{H}$-thymidine.

\section{Western blot analysis}

Pacl were seeded at a density of $4 \times 10^{4}$ cells $/ \mathrm{mL}$ and cultured until cells were $80 \%$ confluent in $100 \mathrm{~mm}^{3}$ dishes. The day prior to treatment, the cells were serum-reduced in $0.1 \%$ fetal bovine serum and 199 medium with gentamicin (Invitrogen) or $0.1 \%$ fetal bovine serum in ACSF. Twenty-four hours after serum reduction, cells were treated with $100 \mathrm{nM}$ rat urotensin II (Sigma Aldrich), and $250 \mathrm{nM}$ STO609, a synthetic 7-oxo-7H-benzimidazo [2,1-a]benz[de] isoquinoline-3-carboxylic acid-acetic acid peptide (Sigma Aldrich). All treatment conditions were carefully selected based on preliminary dose- and time-dependent studies. Experiments with the use of inhibitors were conducted under optimal conditions, and the concentrations were based on previous studies as referenced earlier. Inhibitors were incubated 30 minutes prior to urotensin II treatments. Doseresponse and time-course investigations were conducted with urotensin II treatment. Cells were lysed using RIPA buffer (50 mM TrisHCl, $150 \mathrm{mM} \mathrm{NaCl}, 2 \mathrm{mM}$ ethylenediamine tetraacetic acid, $1 \%$ NP-40, and $0.1 \%$ sodium dodecyl sulfate $\mathrm{pH}$ 7.4) and a protease inhibitor cocktail (Sigma Aldrich) containing phosphate inhibitors. Protein concentration was measured by the bicinchoninic acid method. Equal amounts of protein $(20-30 \mu \mathrm{g})$ were loaded and electrophoresed in $10 \%$ sodium dodecyl sulfate-acrylamide gel. Proteins were transferred to PVDF membrane (Millipore, Billerica, MA). The membrane was incubated with respective phosphospecific primary antibodies at $4^{\circ} \mathrm{C}$ overnight and with corresponding horseradish peroxidase-conjugated secondary antibody at room temperature for one hour. After washing with $1 \times$ phosphate-buffered solution three times at room temperature, the phosphorylation state of the proteins were detected by chemiluminescence (GE Healthcare Amersham). Phosphospecific antibodies used for the Western blots were p-ERK1/2 (Cell Signaling-9106S), p-PKD (Cell Signaling, Boston, MA) and pCaMKI (threonine 178, T Soderling Vollum Institute, Oregon Health Science University, Portland, OR). Loading control was determined by stripping the blot and reprobing with anti-beta actin antibody (Santa Cruz Biotech, Santa Cruz, CA). Expression of the urotensin II receptor was measured using anti-GPR14R (antibody for the urotensin II, Alpha Diagnostic International Inc., San Antonios, TX) antibody.

\section{Adenoviral infection}

Pacl were seeded into six-well plates. Cells were grown in 199 medium containing 10\% serum with penicillin and streptomycin. Cells were allowed to reach near confluency and were infected with the adenovirus Ad- urotensin II and Ad-GO-GFP. The adenovirus-containing (Ad-urotensin IIGFP) and the control adenovirus (Ad-GO-GFP) were both obtained from Walter Thomas (Baker Heart Research Institute, Melbourne, Australia). ${ }^{25}$ Plaque forming units (PFU) in HEK293 cells were measured to determine the viral titer, which was approximately $1.5 \times 107 \mathrm{PFU} / \mathrm{mL}$. The efficiency of infection for viral load was determined by observation of GFP fluorescence under the microscope. Virus-containing media was washed from the cells, and $10 \%$ serum-containing media was incubated for 18 hours for expression of virus. 


\section{Statistical analysis}

Western blot densitometry values were normalized and evaluated relative to control. $\mathrm{Ca}^{2+}$ imaging data were presented relative to control in terms of percentage change. Densitometry, $\mathrm{Ca}^{2+}$, and proliferation data were subjected to one-way analysis of variance (ANOVA, GraphPad-Prism, San Diego, CA) and the Newman-Keuls multiple range test was used for pairwise comparisons of the means. Statistical significance was indicated by $P \leq 0.05$.

\section{Results}

\section{Urotensin II receptor is expressed in Pacl and PAVSMC}

To investigate urotensin II-induced signaling, we used both Pac1 and PAVSMC to verify the expression of the urotensin II receptor. Pac1 are rapidly dividing cells, ${ }^{11}$ and therefore may not accurately represent the characteristics observed in normal vascular smooth muscle cells. Thus, we incorporated the two cell types to identify the urotensin II receptor signaling mechanisms. Previous studies have identified urotensin II receptor expression in PAVSMC, but urotensin II receptor expression in Pac1 lines have not been examined. ${ }^{10}$ Western blot analysis confirms that Pac1 have higher levels of the urotensin II receptor compared with PAVSMC (Figure 1A). Immunocytostaining of both cell types with anti-urotensin II receptor antibody indicated the presence of the urotensin II receptor in both Pac1 and PAVSMC (Figure 1B).

A

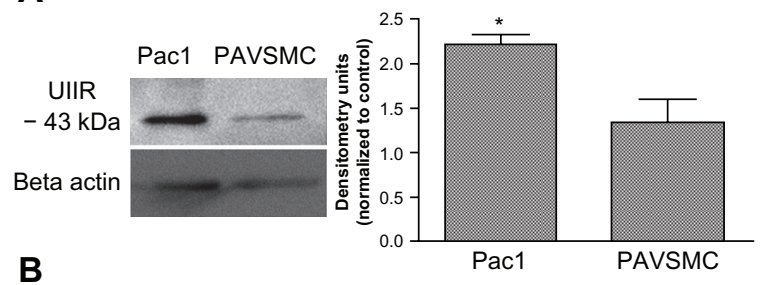

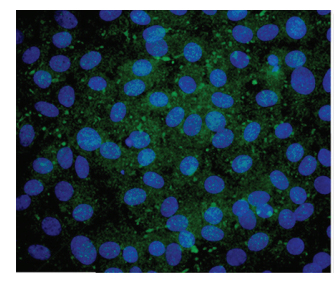

Pac1

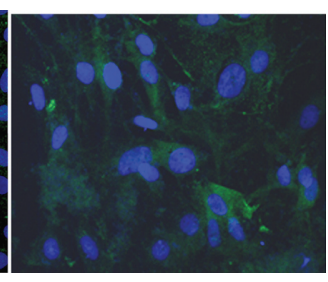

PAVSMC
Figure I Urotensin II is expressed in Pacl and PAVSMC. A) A representative immunoblot using anti-GPR I4 (antibody to urotensin II) demonstrates that urotensin II is expressed in both Pacl and PAVSMC. Densitometry analysis was conducted on Western blots $(n=3, * P \leq 0.05)$. B) Merged image urotensin II immunocytochemistry in Pacl (image $20 \times$ objective) and PAVSMC (image $40 \times$ objective) cells is highlighted by the green stain using anti-GPRI4 antibody (antibody to urotensin II) and the nuclei staining is identified with DAPI, which is shown in blue.

Abbreviations: Pacl, pulmonary arterial vascular smooth muscle cells; PAVSMC, primary aortic vascular smooth muscle cells.

\section{Urotensin II induces mobilization of $\mathrm{Ca}^{2+}$ in Pacl and PAVSMC}

It is well established that binding of urotensin II to the urotensin II receptor leads to mobilization of intracellular $\mathrm{Ca}^{2+}{ }^{26}$ We measured intracellular $\mathrm{Ca}^{2+}$ transients in urotensin IItreated Pac1 and PAVSMC using Fura-2-AM dye and digital imaging microfluorometry. Figures $2 \mathrm{~A}$ and $2 \mathrm{~B}$ demonstrate that urotensin II increases $\mathrm{Ca}^{2+}$ to $800 \mathrm{nM}$ over 30 seconds in Pac1 (Figure 2A) and $600 \mathrm{nM}$ in PAVSMC (Figure 2B). Pac1 and PAVSMC (Figure 2C) are representative images before and after urotensin II treatment. The Fura-2-AM scale,
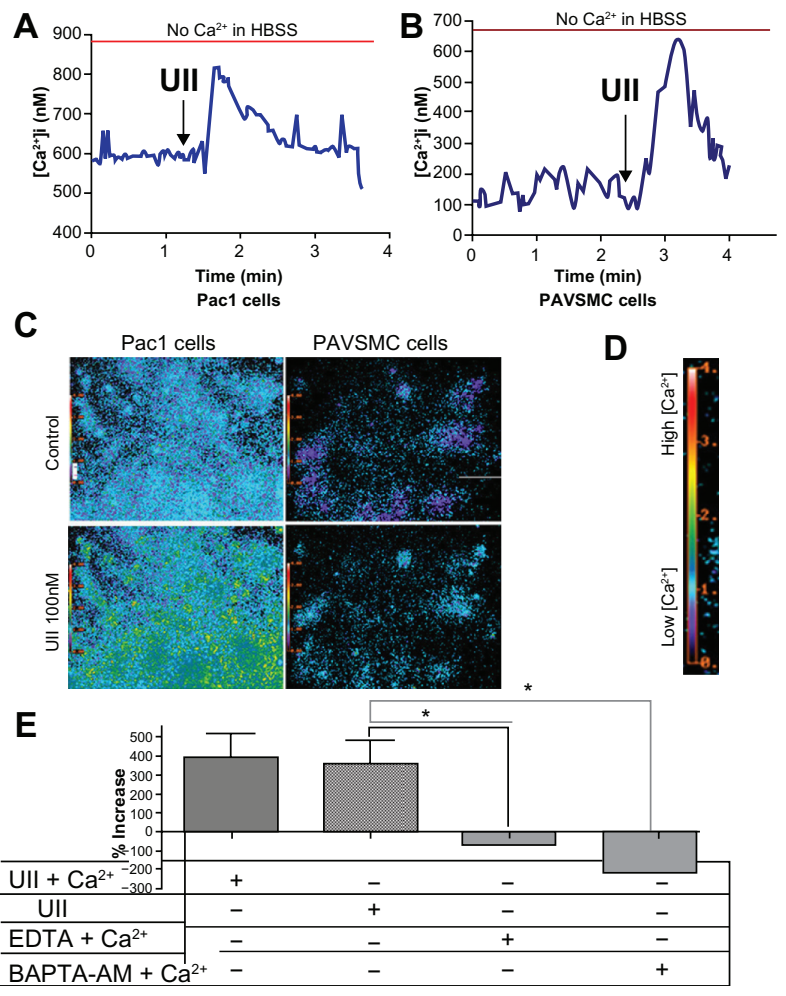

Figure 2 Urotensin II induces elevated levels of intracellular $\mathrm{Ca}^{2+}$ in $\mathrm{Pacl}$ and PAVSMC. Modulation of intracellular $\mathrm{Ca}^{2+}$ in response to urotensin II treatment in Pacl (A) and PAVSMC (B) preloaded with Fura-2 and treated with urotensin II. Cells were captured at the $340 / 380$ fluorescence ratio of Fura-2 and cells were monitored to detect changes in $\mathrm{Ca}^{2+}$. Urotensin II concentrations were chosen according to our previous dose response studies. Data are from an average of $\mathrm{Ca}^{2+}$ response in a population of $\operatorname{PaCl}(\mathbf{A})$ and PAVSMC (B) stimulated with urotensin II $(n=14)$, and a representation of three independent experiments of urotensin II treatment in PaCl and PAVSMC were graphically plotted. Urotensin II-induced mobilization of $\mathrm{Ca}^{2+}$ response was plotted as $\mathrm{Ca}^{2+}$ concentration versus time. D) A representative scale demonstrating the correlation between color and $\mathrm{Ca}^{2+}$ levels. High levels of $\mathrm{Ca}^{2+}$ are shown with bright colors (yellow/red/orange) and low levels correspond to the dark colors (violet/blue/green). C) Fluorescent images of Pacl and PAVSMC C cells were captured with preloaded Fura-2 AM and urotensin II treatment. Images depict (C-top) control and (C-bottom). E) Pacl cells were treated with urotensin II and Hanks Balanced Salt Solution $\pm \mathrm{Ca}^{2+}$. These treatment groups were compared to determine if intracellular $\mathrm{Ca}^{2+}$ is the predominant source. Pac I exposed to membrane-impermeable ethylenediamine tetraacetic acid and membrane-permeable BAPTA-AM were used to reverse the elevated levels of $\mathrm{Ca}^{2+}$. Experiments were conducted in three separate experiments $(n=14, * P \leq 0.05)$.

Abbreviations: Pacl, pulmonary arterial vascular smooth muscle cells; PAVSMC, primary aortic vascular smooth muscle cells. 
as shown in Figure 2D, illustrates the level of intracellular $\mathrm{Ca}^{2+}$, demonstrating that urotensin II induces an increase in $\mathrm{Ca}^{2+}$. In Figure 2E we show that urotensin II-induced $\mathrm{Ca}^{2+}$ release does not depend on extracellular $\mathrm{Ca}^{2+}$. The increase in cytoplasmic $\mathrm{Ca}^{2+}$ in response to urotensin II is the same for cells cultured in Hanks Balanced Salt Solution media with or without $\mathrm{Ca}^{2+}$. Ethylenediamine tetraacetic acid (membrane-impermeable) and BAPTA-AM (membranepermeable) served as our controls in Figure 2E. Taken as a whole, the results in Figure 2 suggest that $100 \mathrm{nM}$ urotensin II causes a release of $\mathrm{Ca}^{2+}$ from internal stores in Pac1 and PAVSMC. Urotensin II induces phosphorylation of CaMKI, ERK, and PKD in Pac1. Western blot analysis was used to assess phosphorylation of CaMKI, PKD, and ERK in response to urotensin II (Figures 3A-3F) in Pac1. There was a dose-dependent (Figures $3 \mathrm{~A}-\mathrm{C}$ ) and time-dependent (Figures 3D-F) increase in CaMKI phosphorylation
(Figures 3A and 3D). PKD phosphorylation (Figures 3B and $3 \mathrm{E}$ ), and ERK phosphorylation (Figures $3 \mathrm{C}$ and $3 \mathrm{~F}$ ) in Pac1 treated with urotensin II. Using $100 \mathrm{nM}$ urotensin II, CaMKI phosphorylation was maximal at 10 minutes, and preceded PKD phosphorylation, which peaked at $15 \mathrm{~min}$ utes. Phosphorylation of ERK occurred later and was still increasing at 60 minutes.

\section{Urotensin II-induced phosphorylation of CaMKI, PKD, and ERK reduced in presence of CaMKK inhibitor in Pacl}

To test if CaMKK is an integral target affecting the activation of several downstream effectors in the urotensin II signaling cascade, we used the CaMKK inhibitor prior to the addition of $100 \mathrm{nM}$ urotensin II for 10 minutes, and measured CaMKI phosphorylation via Western blot analysis (Figure 4A). Our results in Figure 4A revealed that STO609 blocked the

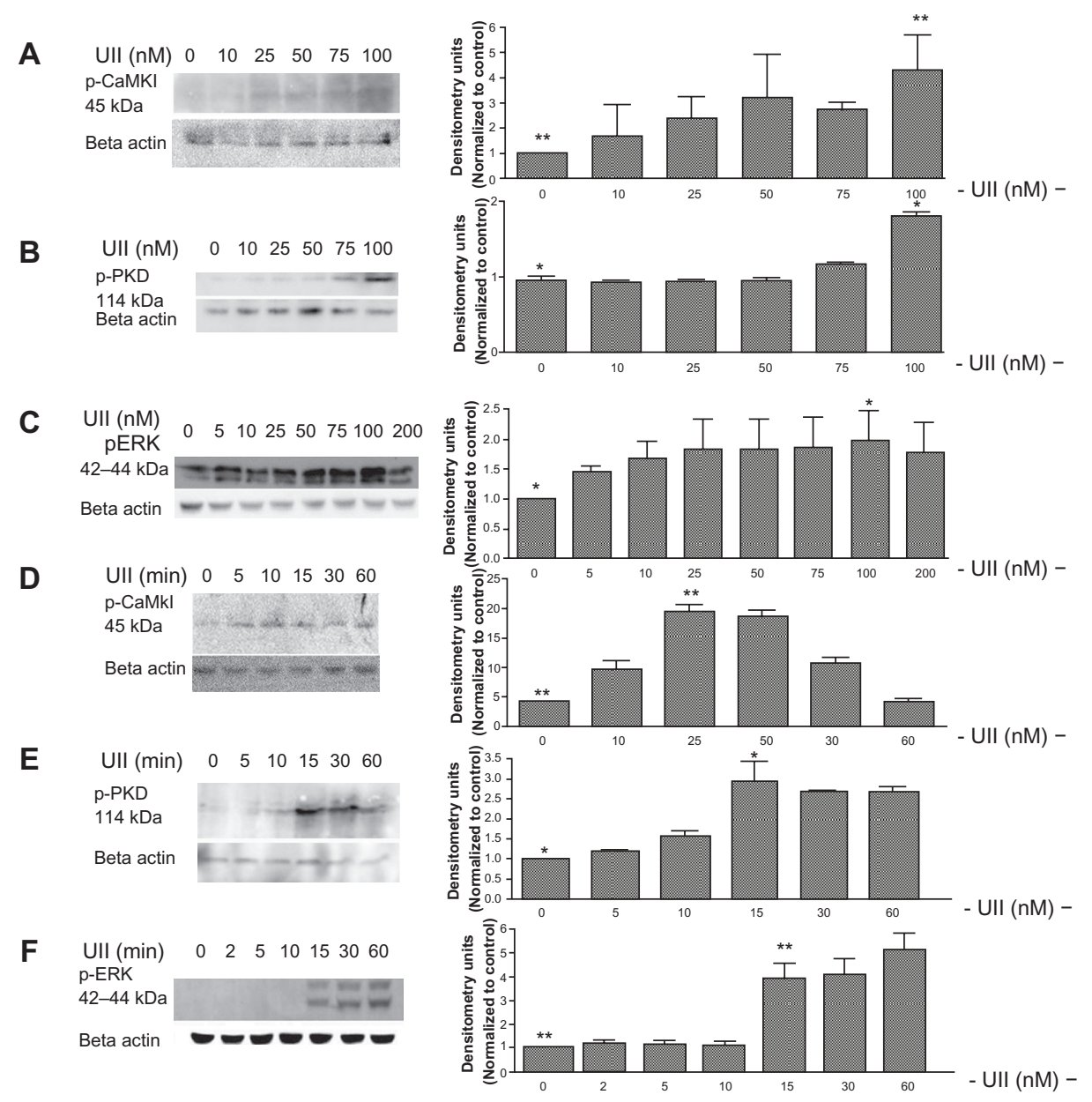

Figure 3 Urotensin II induces phosphorylation of CaMKI, PKD, and ERK in Pacl. Western blot analysis of the time course of CaMKI, PKD, and ERK phosphorylation (A, B, and $\mathbf{C}$ ) and dose response of urotensin II-stimulated phosphorylation CaMKI, PKD, and ERK (D, E, and F) in Pacl cells. Densitometry analysis was conducted on Western blots $(\mathrm{n}=3, * \mathrm{p} \leq 0.05$, **P $\leq 0.0 \mathrm{l})$.

Abbreviations: Pacl, pulmonary arterial vascular smooth muscle cells; PAVSMC, primary aortic vascular smooth muscle cells; PKD, protein kinase D; CaMKI, Ca ${ }^{2+}$ calmodulin-dependent kinase Type I; ERK, extracellular signal-regulated kinase. 

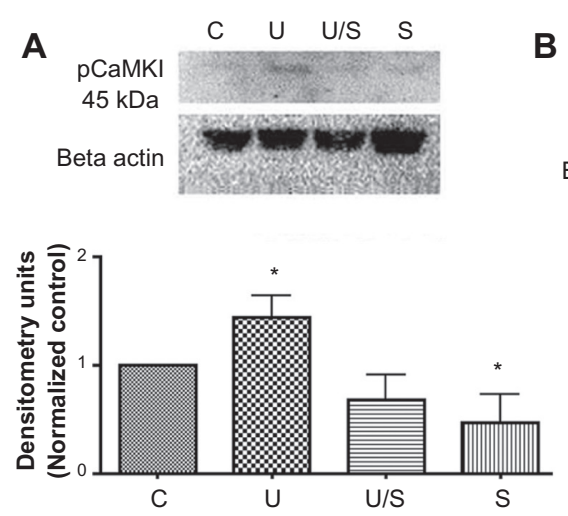

B
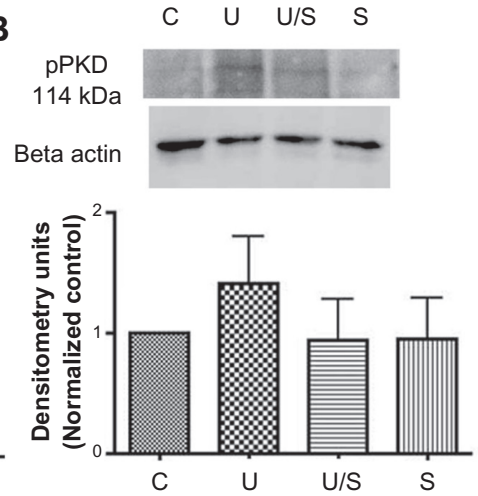

C U U/S S
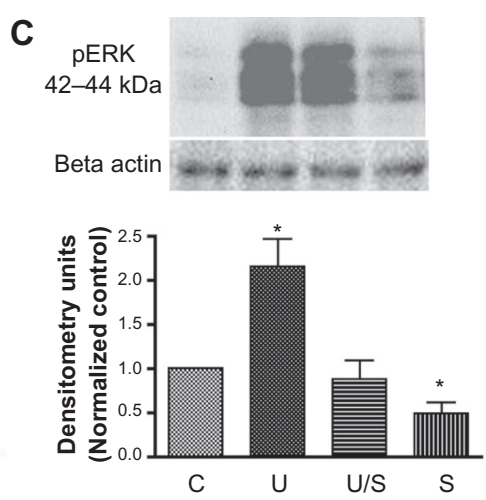

Figure 4 Urotensin II receptor-induced phosphorylation of CaMKI, PKD, and ERK is inhibited by CaMKK inhibitor in Pacl. Urotensin II receptor-induced phosphorylation of A. CaMKI, B. PKD, and C. ERK inhibited by CaMKK. Densitometry analysis was conducted on Western blots $(n=4$, $* P \leq 0.05)$.

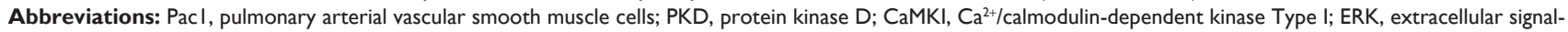
regulated kinase; C, control; UII, urotensin II; U/S, urotensin II \pm STO609.

urotensin II-induced phosphorylation of CaMKI. We also pretreated Pac1 with $250 \mathrm{nM}$ STO609 for 30 minutes, followed by a treatment of $100 \mathrm{nM}$ urotensin II for 15 minutes to measure PKD phosphorylation (Figure 4B). Our findings demonstrated a reduction in urotensin II-stimulated PKD phosphorylation in the presence of STO609 (Figure 4B). We then used $250 \mathrm{nM}$ STO609 for a 30-minute pretreatment, followed by a treatment of $100 \mathrm{nM}$ urotensin II for 30 minutes. Under these treatment conditions, STO609 reduced urotensin II-induced ERK phosphorylation in Pac1 (Figure 4C). By and large, the inhibition of CaMKK reduces urotensin II-induced phosphorylation of CaMKI, PKD, and ERK (Figure 4). Therefore, our results with STO609 establish CaMKK's involvement in urotensin II receptor signaling (Figure 4).

\section{Characterization of primary cell cultures}

Urotensin II-induced signaling mechanisms are poorly understood in vascular smooth muscle cells, therefore we looked at urotensin II receptor signaling in both a cell line and a primary culture. We verified isolation of primary rat aortas by immunostaining the cells with a smooth muscle cell-specific antibody-antimyosin primary antibody for smooth muscle cells. As shown in Figure 5A, more than 70\% of PAVSMC are smooth muscle cell-positive. Western blot analysis was used to determine if urotensin II treatment of PAVSMC induces ERK phosphorylation. Our results demonstrate that PAVSMC exposed to $100 \mathrm{nM}$ urotensin II induces phosphorylation of ERK maximally after 15 minutes (Figure 5B). Furthermore, 30 minutes of pretreatment with $250 \mathrm{nM}$ STO609 blocked urotensin II-induced ERK phosphorylation in PAVSMC (Figure 5C). Therefore, our results demonstrate that urotensin II induces the phosphorylation of ERK in PAVSMC, and CaMKK exposure to PAVSMC blocks urotensin II-induced phosphorylation of ERK (Figure 5).

\section{Urotensin II stimulates proliferation of Pacl and PAVSMC}

Studies have linked urotensin II-induced ERK phosphorylation with cellular proliferation in thoracic aortic cells. ${ }^{21}$ Therefore, we tested whether urotensin II induces cellular proliferation in Pac1 and PAVSMC. We measured ${ }^{3} \mathrm{H}$-thymidine uptake as a proliferative assay in Pac1 (Figure 6A) and PAVSMC (Figure 6B). Cellular proliferation was measured by counting numbers of Pac1, and we found that the cell number is greater with urotensin II treatment (Figure 6C). Representative images of urotensin II-treated Pac1 were taken to show differences in cell numbers with urotensin II treatment (Figure 6D). Urotensin II induced proliferation of both cell types in a dose-dependent manner (Figure 6).

CaMKK inhibitor blocks urotensin II-induced cellular proliferation in Pacl and PAVSMC

Pretreatment with STO609 to inhibit CaMKK blocks urotensin II-induced proliferation of PAVSMC (Figure 7A and B) and Pac1 (Figure 7C). Representative images were taken (Figure 7E), and cellular proliferation was measured by counting cell numbers to show that STO609 blocks urotensin II-induced proliferation in Pac1 (Figure 7D).

\section{Extracellular $\mathrm{Ca}^{2+}$ does not alter urotensin II-induced} phosphorylation of CaMKI and cellular proliferation To determine if $100 \mathrm{nM}$ urotensin II in the presence of extracellular $\mathrm{Ca}^{2+}$ alters CaMKI phosphorylation, the urotensin II-induced phosphorylation status of CaMKI was 
A

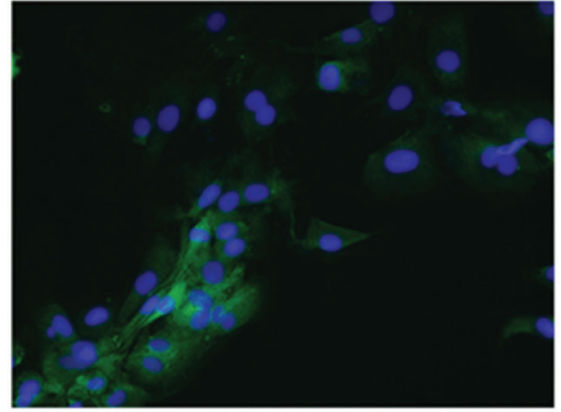

PAVSMC cells
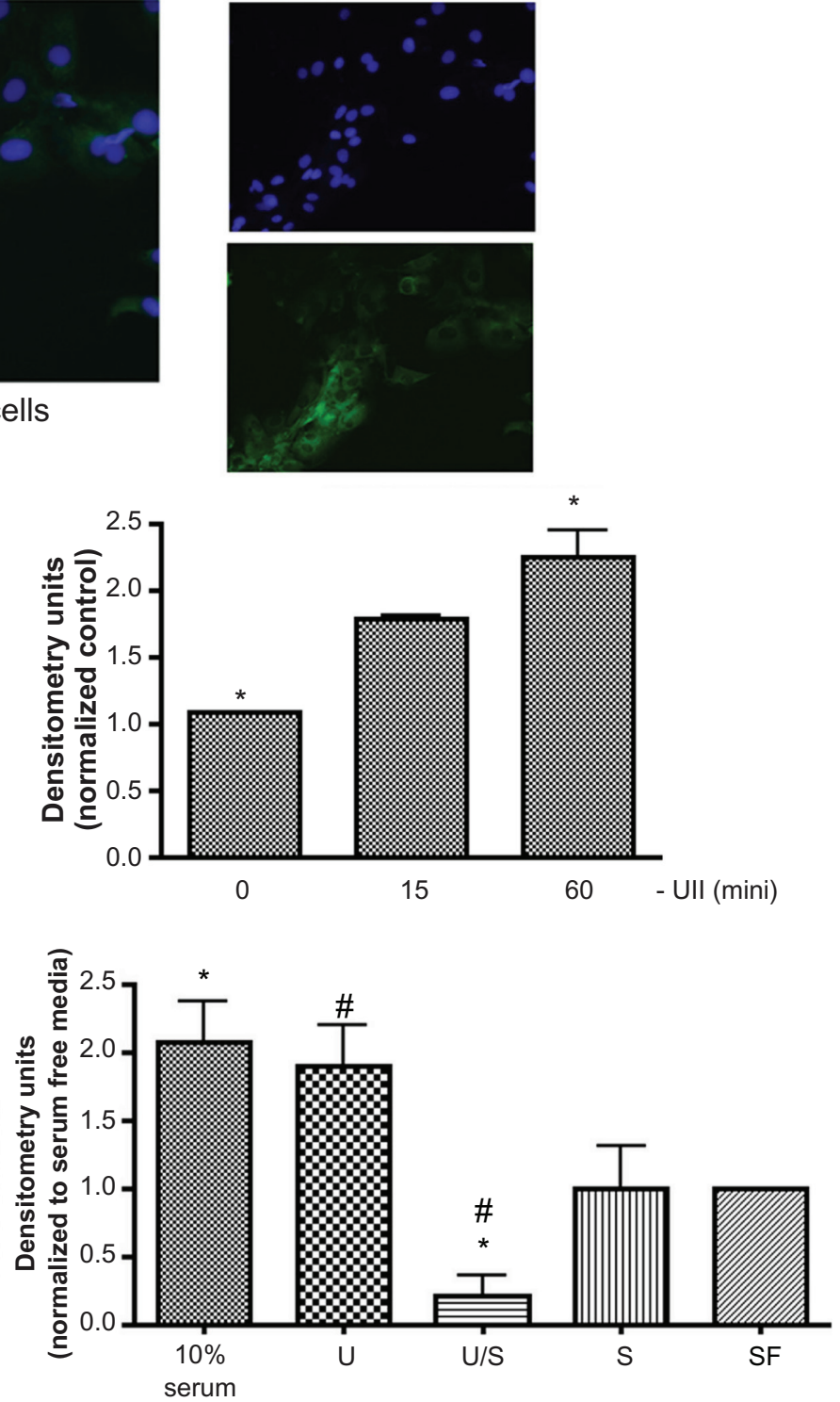

Figure 5 Characterization of PAVSMC. A) PAVSMC were immunostained with antimyosin smooth muscle cell-specific antibody to identify if cultured cells are composed of vascular smooth muscle cells. Merged image of cultured PAVSMC depicts positive antimyosin smooth muscle cell staining (left image). Antimyosin smooth muscle cell antibody is highlighted by the green stain (top image), and the nuclei staining is identified with DAPI, which is shown in blue (bottom image). B) A representative immunoblot demonstrates that urotensin II induces ERK phosphorylation in a time-dependent manner. Densitometry analysis was conducted on Western blots $(n=3$, $* P \leq 0.05$. C) and D) A representative Western blot demonstrating that CaMKK blocks urotensin II receptor-induced phosphorylation of ERK (I0\% serum and I0\% fetal bovine serum in media $\left(\mathrm{n}=2, * P \leq 0.05,{ }^{*} P \leq 0.05\right)$.

Abbreviations: PAVSMC, primary aortic vascular smooth muscle cells; ERK, extracellular signal-regulated kinase; C, control; UII, urotensin II; U/S, urotensin II \pm STO609; SF, reduced serum media.

measured in $0.1 \%$ fetal bovine serum in ACSF media in the presence and absence of $\mathrm{Ca}^{2+}$ via Western blot analysis (Figure $8 \mathrm{~A}$ and $8 \mathrm{~B}$ ). The results indicated no statistical difference between treatment groups (ACSF + urotensin II) and (ACSF + urotensin $\mathrm{II}+\mathrm{Ca}^{2+}, \mathrm{n}=3$, Figure $8 \mathrm{~B}$ ). To address the role of extracellular $\mathrm{Ca}^{2+}$ and $100 \mathrm{nM}$ urotensin II-induced cellular proliferation, we treated cells for 24 hours with reduced serum ACSF in the presence and absence of $\mathrm{Ca}^{2+}$ and measured cellular proliferation via ${ }^{3} \mathrm{H}$-thymidine incorporation assay (Figure 8C). Results in Figure 8C demonstrate that urotensin
II treatment in ACSF media, in the presence or absence of $\mathrm{Ca}^{2+}$, did not alter the levels of cellular proliferation.

\section{Urotensin II overexpression enhances ERK phosphorylation and proliferation of Pacl}

In order to delineate whether urotensin II-induced signaling occurs through the urotensin II receptor, cells were kept in reduced serum for treatment groups (Ad-GoGFP, Ad-urotensin II receptor, Ad-urotensin II receptor + urotensin II, Ad-urotensin II receptor + urotensin II + STO609). 
A

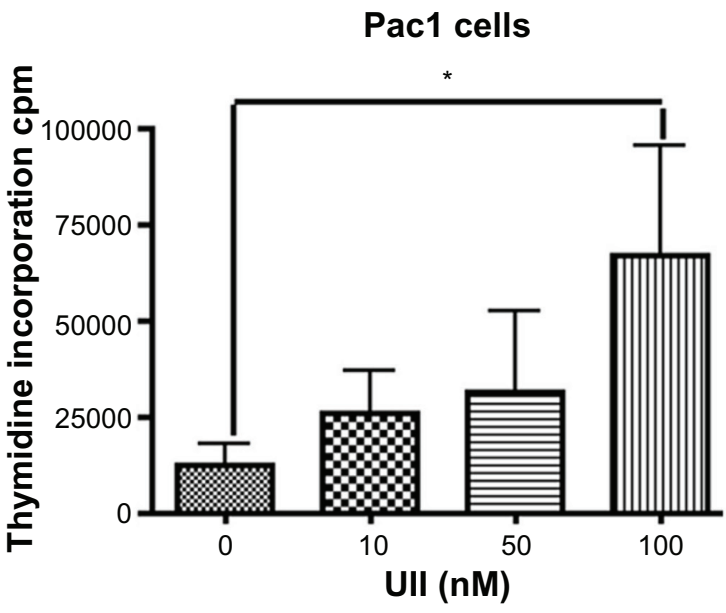

B

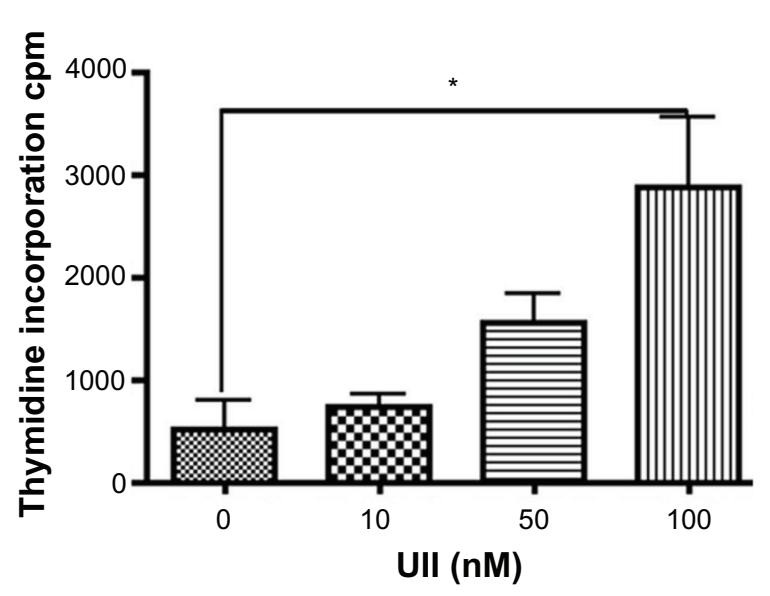

C

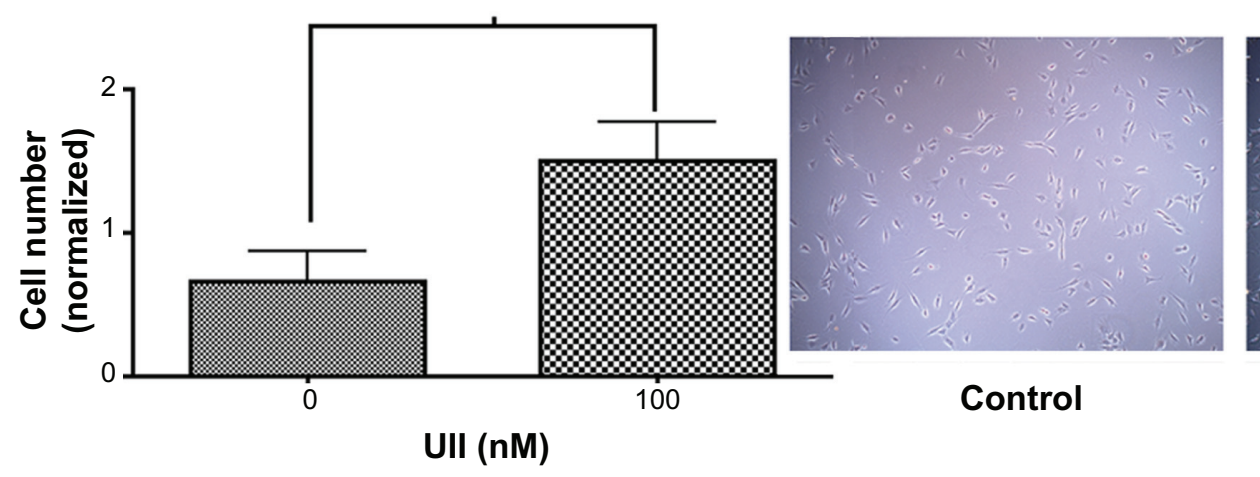

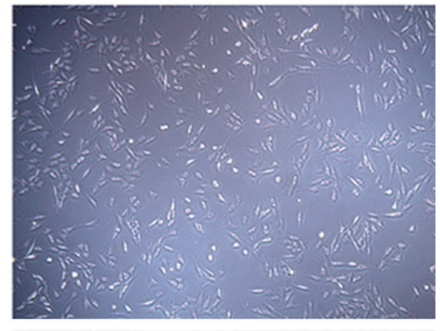

100 nM UII

Figure 6 Urotensin II-induced cellular proliferation in a dose-dependent manner. ${ }^{3} \mathrm{H}$-thymidine uptake in A. Pacl and B. PAVSMC treated with urotensin II in a dose-dependent manner stimulates proliferation $(n=4, * P \leq 0.0 I)$. C) Cell counting was used as a measure of cellular proliferation in Pac. Experiment was blinded and six independent experiments were conducted with triplicates $(n=18$, $* P \leq 0.05)$. D) A representative image of control and I $00 \mathrm{nM}$ urotensin II (image $20 \times$ objective) in Pacl.

Abbreviations: Pacl, pulmonary arterial vascular smooth muscle cells; PAVSMC, primary aortic vascular smooth muscle cells; UII, urotensin II.

We overexpressed the urotensin II receptor by infecting Pac1 with a urotensin II receptor adenovirus (Ad-urotensin II) in the presence and absence of urotensin II or STO609. Ten percent of serum-treated cells in the presence of the Ad-urotensin II receptor were compared with the reduced serum treatment groups to determine if urotensin II or full serum specifically affects the urotensin II receptor proliferation signaling pathway. We measured downstream targets, such as ERK phosphorylation (Figure 9A), and cellular proliferation (Figures 9B-D). Our results reveal that urotensin II receptor overexpression enhances urotensin II-induced ERK phosphorylation and cellular proliferation of Pac1.

\section{Discussion}

The results reported here demonstrate that urotensin II induces $\mathrm{Ca}^{2+} /$ calmodulin-dependent kinase-dependent proliferation of Pac1 and PAVSMC. Furthermore, our present study identified that, in vascular smooth muscle cells, urotensin II-induced phosphorylation of several urotensin II receptor downstream targets can be blocked using a CaMKK inhibitor. These findings suggest that CaMKK inhibition may have therapeutic relevance by blocking cellular proliferation in Pac1 and PAVSMC.

The urotensin II receptor signaling pathway was initially thought to be activated by the single agonist, urotensin II. ${ }^{5}$ However, recent evidence identified urotensin II-related peptide as an additional agonist of the urotensin II receptor, similarly activating urotensin II-induced downstream targets..$^{27}$ Both agonists have been observed to play a role in disease processes, although the scope of our study did not include urotensin II-related peptide effects on urotensin II receptor signaling. ${ }^{27,28}$ Hirose et al demonstrated that during heart failure, urotensin II-related peptide expression is 
A Treatment (24 hr) Pac1 cells

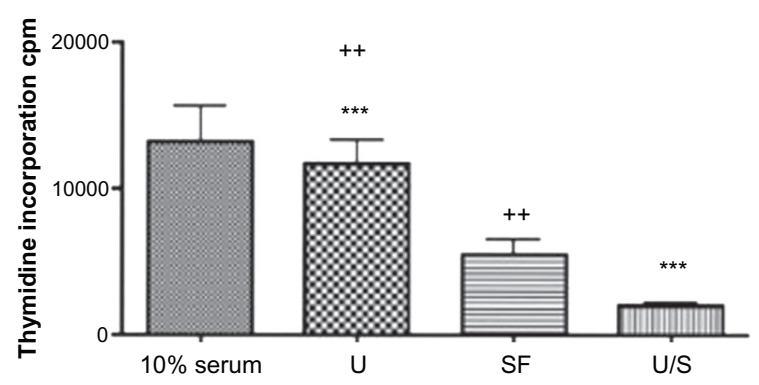

C

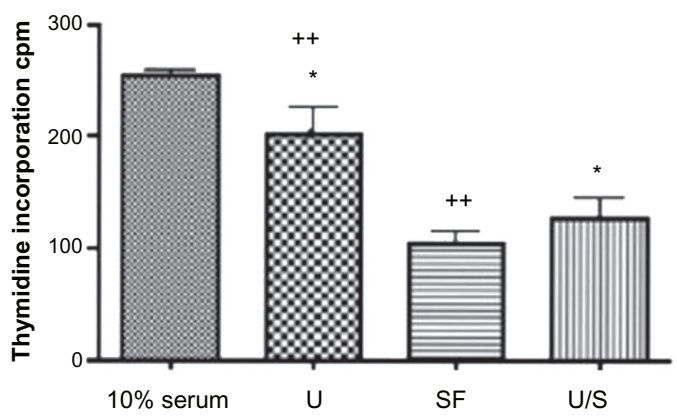

Treatment (24 hr) PAVSMC cells
B

Treatment (48 hr) Pac1 cells

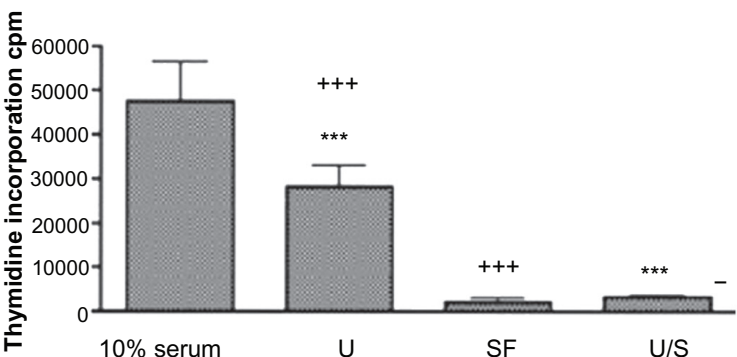

E

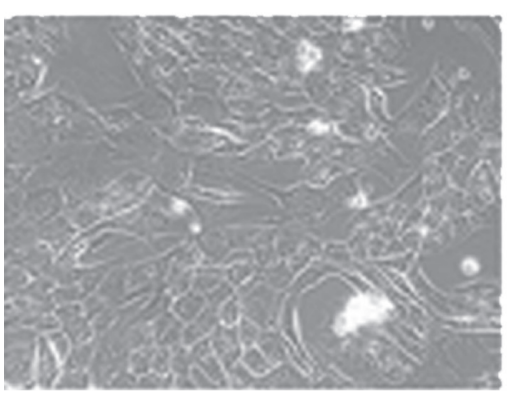

C

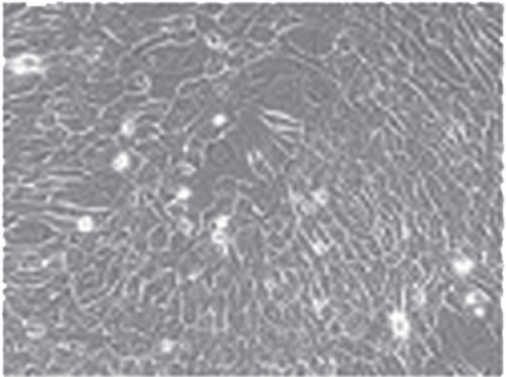

U

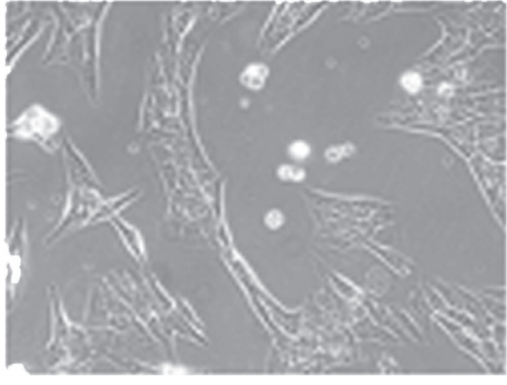

$\mathrm{U} / \mathrm{S}$

Figure 7 CaMKK inhibitor reduces urotensin II-induced cellular proliferation in Pacl and PAVSMC. Proliferation studies involved serum starvation for A 24 hours and $\mathbf{B}$ 48 hours. Pacl were treated with urotensin II and were measured via ${ }^{3} \mathrm{H}$-thymidine incorporation assay. Inhibitor studies using CaMKK inhibitor in the presence of urotensin II were conducted in Pacl (A and B) and PAVSMC (C), and were analyzed through ${ }^{3} \mathrm{H}$-thymidine incorporation as a measurement of cellular proliferation (I0\% serum and $10 \%$ fetal bovine serum in media $\left(n=4, * P \leq 0.05,+P \leq 0.01,{ }^{+}+P \leq 0.001\right.$, $\left.* * * P \leq 0.001\right)$. C) Cell counting was performed as a method to measure cellular proliferation (three independent experiments, $n=18, P \leq 0.05$ ). E) A representative image was taken comparing cellular proliferation in Pacl cells (image $40 \times$ objective).

Abbreviations: Pacl, pulmonary arterial vascular smooth muscle cells; CaMKK, Ca ${ }^{2+} /$ calmodulin-dependent kinase kinase; PAVSMC, primary aortic vascular smooth muscle cells; U, urotensin II, U/S, urotensin II \pm STO609; SF, reduced serum medium.

increased in the atrium and right ventricle of the heart. ${ }^{29}$ Within the past decade, studies have observed the effects of urotensin II binding of the urotensin II receptor in various tissues including the brain, kidney, heart, and vessels. $.^{30} \mathrm{Cel}-$ lular proliferation in all these tissue types, except for heart, has shown a close correlation with increases in urotensin II levels. ${ }^{30}$ Previous studies involving human umbilical vein cells show that urotensin II induces ERK phosphorylation and cellular proliferation. ${ }^{20}$ ERK has been recognized as a target for several G-protein coupled receptors, and its activation is correlated with proliferation. ${ }^{18,31}$ ERK activation is dependent on several intracellular signals, including an increase in intracellular $\mathrm{Ca}^{2+} .{ }^{32}$ Tamura et al has shown that urotensin II receptor signaling stimulates ERK phosphorylation via the classical pathways involving Ras and Raf in primary thoracic aortic cells. ${ }^{21}$ Conversely, Sauzeau et al revealed via BrdU and cell counting assays that urotensin II stimulates human aortic smooth muscle cell proliferation through RhoA and Rho kinase. ${ }^{33}$ Although our studies indicate that activation of cell proliferation by the 


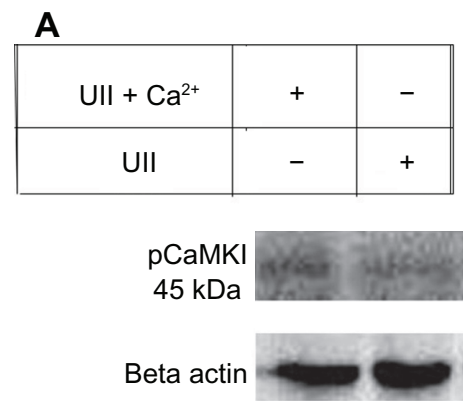

C
B

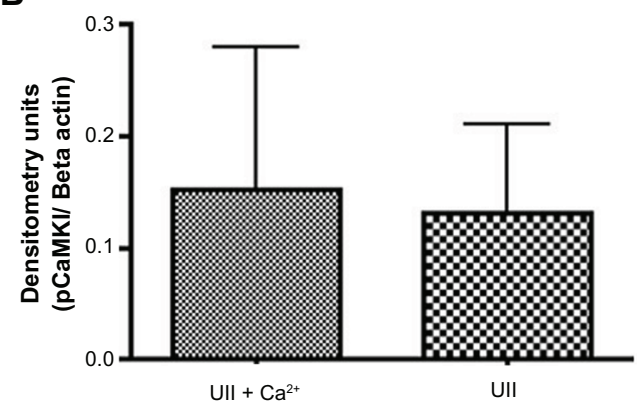

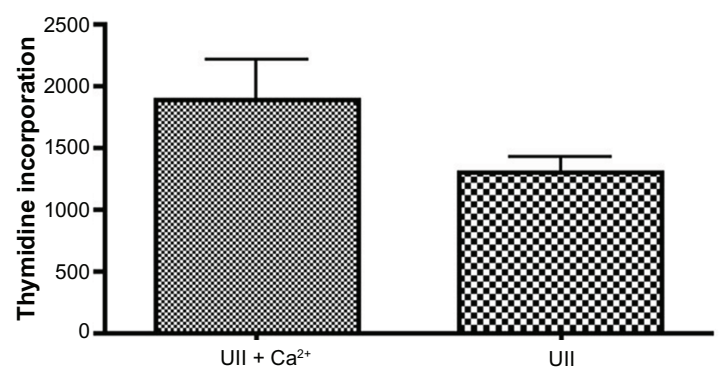

Figure 8 Intracellular $\mathrm{Ca}^{2+}$ is the predominant source of $\mathrm{Ca}^{2+}$ involved in urotensin Il-induced phosphorylation of CaMKI and cellular proliferation in Pacl. A) A representative immunoblot demonstrates that urotensin II-induced phosphorylation of $\mathrm{CaMKI}$ is independent of extracellular $\mathrm{Ca}^{2+}$. Pacl were treated with ACSF + urotensin II $\pm \mathrm{Ca}^{2+}$. B) Densitometry analyses of treatment groups are compared in pairwise t-tests. The $y$-axis data is plotted as a fraction of control ( $\mathrm{n}=2$ ). C) Proliferation studies conducted in Pacl were measured via ${ }^{3} \mathrm{H}$-thymidine incorporation in Pacl. Treatment groups for ACSF + urotensin II $\pm \mathrm{Ca}{ }^{2}$ were compared in a pairwise t-test $(n=4)$.

Abbreviations: Pacl, pulmonary arterial vascular smooth muscle cells; ACSF, isotonic artificial CSF; CAMKI, Ca ${ }^{2+} / \mathrm{calmodulin}^{-d e p e n d e n t ~ k i n a s e ~ T y p e ~ I . ~}$

urotensin II receptor and its Gq-coupled receptor requires $\mathrm{Ca}^{2+}$ activation of CaMK, it is possible that induction of Ras/Raf or Rho kinase pathways may also be involved. Schmidt et al had shown in hippocampal cells that CaMKI stimulates ERK phosphorylation, and conversely reduced ERK phosphorylation using a dominant negative CaMKI or pharmacologic inhibitors to CaMKI, which is consistent with our findings. ${ }^{20}$

Previous studies examining cellular proliferation identified the sarcoplasmic reticulum as the predominant source of $\mathrm{Ca}^{2+}$ release during proliferation. Dramatic changes in $\mathrm{Ca}^{2+}$ flux have been linked to cardiovascular disease, such as arteriosclerosis and renal disease. ${ }^{34,35}$ However, the mechanisms inducing intracellular $\mathrm{Ca}^{2+}$ flux are not yet well defined. Others have demonstrated that $\mathrm{Ca}^{2+}$ / ATPase and sarco/endoplasmic reticulum $\mathrm{Ca}^{2+}$-ATPase pumps could modulate cytoplasmic $\mathrm{Ca}^{2+}$ increases during proliferation.$^{37}$ Recent proliferation studies have shown that the intracellular store involved in sarcoplasmic reticulum release (via $\mathrm{Ca}^{2+}$-induced $\mathrm{Ca}^{2+}$ release) may occur through the ryanondine receptor. ${ }^{36,37}$ We have not identified the source or the specific mechanism of intracellular $\mathrm{Ca}^{2+}$ release, although future studies will entail delineating which intracellular $\mathrm{Ca}^{2+}$ store is involved in the urotensin II-induced signaling pathway. Currently it is our belief that the primary mechanism of this Gq signaling-mediated event occurs through inositol triphosphate and modulates the release of $\mathrm{Ca}^{2+}$.

Although our studies indirectly identify $\mathrm{Ca}^{2+} /$ calmodulin kinases as the target signaling kinases in the urotensin IIurotensin II receptor pathway, future studies are needed to elucidate urotensin II receptor signaling mechanisms using a urotensin II receptor-specific antagonist. We have used an adenovirus to overexpress the urotensin II receptor, although using siRNA to the urotensin II receptor or a direct inhibitor will determine the involvement of $\mathrm{Ca}^{2+} /$ calmodulin kinases in the urotensin II-induced proliferation pathways of vascular smooth muscle cells.

In summary, Pac1 and PAVSMC cultures exposed to urotensin II result in cellular proliferation, and CaMKK inhibitor treatment blocks cellular proliferation. Understanding CaMKK's role in urotensin II-induced proliferation may provide further insight into potential therapeutic targets for vascular smooth muscle cell proliferation. 


\begin{tabular}{|c|ccc|cc|}
\hline AdGFP & + & - & + & - & - \\
\hline AdUIIR & - & + & + & + & + \\
\hline UII & - & + & + & - & - \\
\hline STO609 & - & - & + & - & - \\
\hline $10 \%$ Serum & - & - & - & + & - \\
\hline
\end{tabular}

A

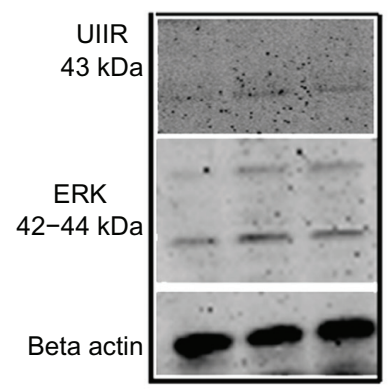

C

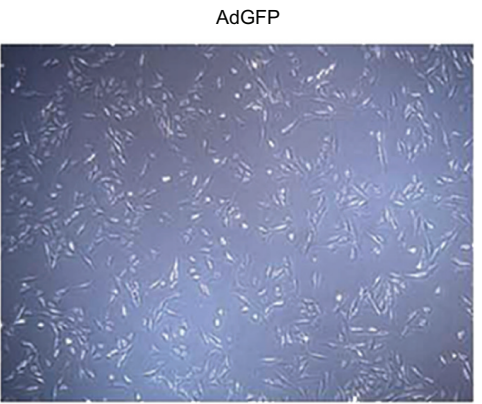

D

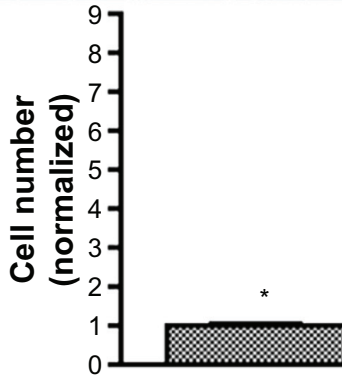

AdGFP

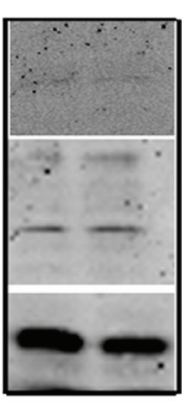

B

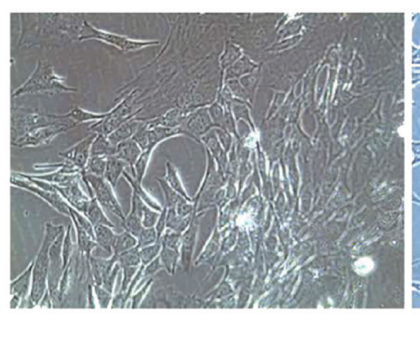

AdUIIR

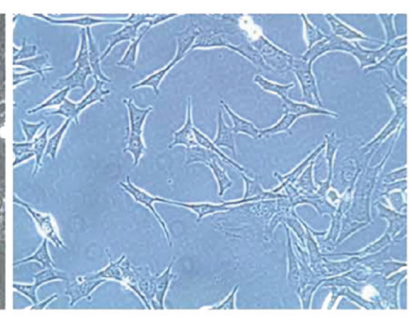

AdUIIR + U
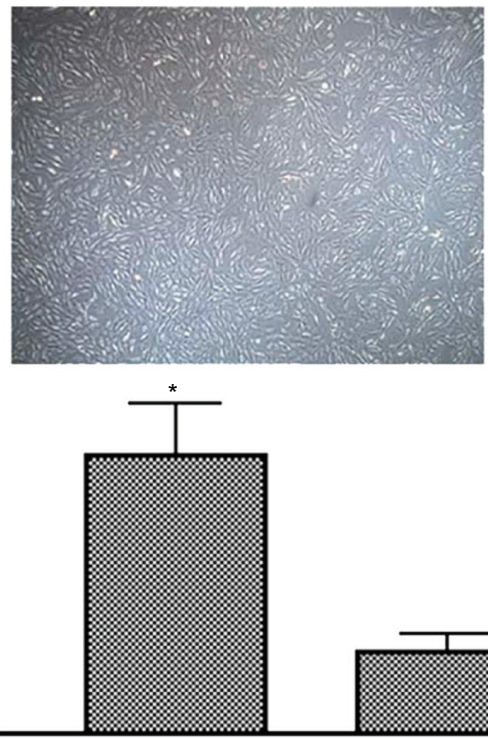

AdUIIR + U

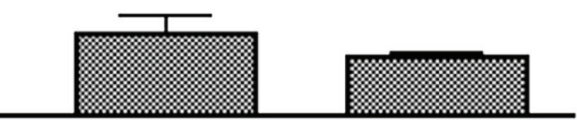

AdUIIR

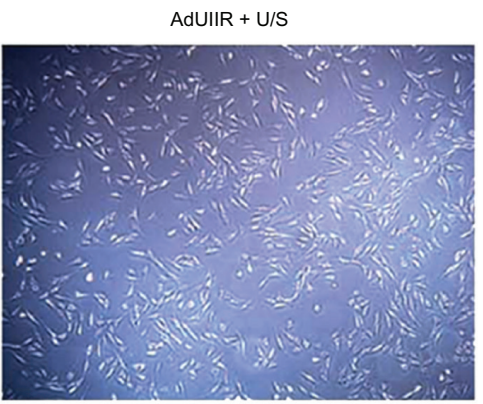

Figure 9 Overexpression of the urotensin II receptor in the presence of urotensin II enhances ERK phosphorylation and cellular proliferation in Pacl cells. A) A representative immunoblot demonstrates that the Ad-urotensin II receptor in the presence of urotensin II, induces ERK phosphorylation in Pacl. B) A representative image of proliferating Pacl were taken of Ad-urotensin II receptor + serum, Ad-urotensin II receptor, (image $40 \times$ objective) and C) Ad-GFP,Ad-urotensin II receptor + urotensin II, Ad-urotensin II receptor + urotensin II + STO609 (image $20 \times$ objective). D) Cellular proliferation determined by cell counting in Pacl, measures Ad-urotensin II receptor in the presence of urotensin II $(\mathrm{n}=2, P \leq 0.0 \mathrm{I})$.

Abbreviations: Ad-, adenovirus infected; Pacl, pulmonary arterial vascular smooth muscle cells; ERK, extracellular signal-regulated kinase.

\section{Disclosure}

The authors report no conflicts of interest in this work.

\section{References}

1. Jeffery TK, Morrell NW. Molecular and cellular basis of pulmonary vascular remodeling in pulmonary hypertension. Prog Cardiovasc Dis. 2002;45(3):173-202.

2. Rudijanto A. The role of vascular smooth muscle cells on the pathogenesis of atherosclerosis. Acta Med Indones. 2007;39(2):86-93.

3. Matsushita M, Shichiri M, Fukai N, et al. Urotensin II is an autocrine/ paracrine growth factor for the porcine renal epithelial cell line, LLCPK1. Endocrinology. 2003;144(5):1825-1831.

4. Cohen JD. Overview of physiology, vascular biology, and mechanisms of hypertension. J Manag Care Pharm. 2007;13 Suppl 5:S6-S8.
5. Watanabe T, Kanome T, Miyazaki A, Katagiri T. Human urotensin II as a link between hypertension and coronary artery disease. Hypertens Res. 2006;29(6):375-387.

6. Matsusaka S, Wakabayashi I. Enhancement of vascular smooth muscle cell migration by urotensin II. Naunyn-Schmiedebergs Arch Pharmacol. 2006;373(5):381-386

7. Matsushita M, Shichiri M, Imai T, et al. Co expression of urotensin II and its receptor (GPR14) in human cardiovascular and renal tissues. $J$ Hypertens. 2001;19(12):2185-2190.

8. Papadopoulos P, Bousette N, Giaid A. Urotensin II and cardiovascular remodeling. Peptides. 2008;29(5):764-769.

9. Hidalgo C, Nunez MT. Calcium, iron and neuronal function IUBMB Life. 2007;59(4-5):280-285. Available at : http://www3. interscience.wiley.com/journal/117879563/abstract?CRETRY= 1\&SRETRY=0. Accessed on Jul 15, 2010. 
10. Wang YX, Ding YJ, Zhu YZ, Shi Y, Yao T, Zhu YC. Role of PKC in the novel synergistic action of urotensin II and angiotensin II and in urotensin II induced vasoconstriction. Am J Physiol Heart Circ Physiol. 2007;292(1):H348-H359.

11. Rothman A, Kulik TJ, Taubman MB, Berk BC, Smith CW, Nidel-Ginard B. Development and characterization of a cloned rat pulmonary arterial smooth muscle cell line that maintains differentiated properties through multiple subcultures. Circulation. 1992;86(6):1977-1986.

12. Cobb MH, Hepler JE, Cheng M, Robbins D. The mitogen activated protein kinases, ERK1 and ERK2. Semin Cancer Biol. 1994;5(4):261-268.

13. Tokumitsu H, Takahashi N, Eto K, Yano S, Soderling TR, Muramatsu M. Substrate recognition by $\mathrm{Ca}^{2+} / \mathrm{Calmodulin}$ dependent protein kinase kinase. Role of the arg pro rich insert domain. J Biol Chem. 1999;274(22):15803-15810.

14. McKinsey TA. Derepression of pathological cardiac genes by members of the CaM kinase superfamily. Cardiovasc Res. 2007;73(4): 667-677.

15. Rozengurt E. Mitogenic signaling pathways induced by G proteincoupled receptors. J Cell Physiol. 2007;213(3):589-602.

16. Shi L, Ding W, Li D, et al. Proliferation and anti apoptotic effects of human urotensin II on human endothelial cells. Atherosclerosis. 2006;188(2):260-264.

17. Brose N, Rosenmund C. Move over protein kinase C, you've got company: Alternative cellular effectors of diacylglycerol and phorbol esters. J Cell Sci. 2002;115(Pt 23):4399-4411.

18. Raiesdana A, Loscalzo J. Pulmonary arterial hypertension. Ann Med. 2006;38(2):95-110.

19. Nakagawa Y, Kuwahara K, Harada M, et al. Class II HDACs mediate CaMK dependent signaling to NRSF in ventricular myocytes. $J \mathrm{Mol}$ Cell Cardiol. 2006;41(6):1010-1022.

20. Schmitt JM, Guire ES, Saneyoshi T, Soderling TR. Calmodulin dependent kinase kinase/calmodulin kinase I activity gates extracellular regulated kinase dependent long term potentiation. $J$ Neurosci. 2005;25(5):1281-1290.

21. Tamura K, Okazaki M, Tamura M, Isozumi K, Tasaki H, Nakashima Y. Urotensin II induced activation of extracellular signal regulated kinase in cultured vascular smooth muscle cells: Involvement of cell adhesion mediated integrin signaling. Life Sci. 2003;72(9):1049-1060.

22. Guibert C, Marthan R, Savineau JP. Modulation of ion channels in pulmonary arterial hypertension. Curr Pharm Res. 2007;13(24):2443-2455.

23. Travo P, Barrett G, Burnstock G. Differences in proliferation of primary cultures of vascular smooth muscle cells taken from male and female rats. Blood Vessels. 1980;17(2):110-116.

24. Dibas A, Prasanna G, Yorio T. Localization of endothelin converting enzyme in bovine optic nerve and retina. J Ocul Pharmacol Ther. 2005;21(4):288-297.
25. Onan D, Pipolo L, Yang E, Hannah RD, Thomas WG. Urotensin II promotes hypertrophy of cardiac myocytes via mitogen activated protein kinases. Mol Endocrinol. 2004;18(9):2344-2354.

26. Ames RS, Sarau HM, Chambers JK, et al. Human urotensin II is a potent vasoconstrictor and agonist for the orphan receptor GPR14. Nature. 1999;401(6750):282-286

27. Jarry M, Diallo M, Lecointre C, et al. The vasoactive peptides urotensin II and urotensin II related peptide regulate astrocyte activity through common and distinct mechanisms: Involvement in cell proliferation. Biochem J. 2010;428(1):113-124.

28. Kristof AS, You Z, Hans YS, Giaid A. Protein expression of urotensin II, urotensin related peptide, and their receptor in the lungs of patients with lymphangioleiomyomatosis. Peptides. 2010 May 28. [Epub ahead of print].

29. Hirose T, Takahashi K, Mori N, et al. Increased expression of urotensin II, urotensin II related peptide and urotensin II receptor mRNAs in the cardiovascular organs of hypertensive rats: Comparison with endothelin 1 . Peptides. 2009;30(6):1124-1129.

30. Yoshimoto T, Matsushita M, Hirata Y. Role of urotensin II in peripheral tissue as an autocrine/paracrine growth factor. Peptides. 2004;25(10): 1775-1781.

31. Soderling TR. The Ca calmodulin dependent protein kinase cascade. Trends Biochem Sci. 1999;24(6):232-236.

32. Harrison BC, Kim MS, van Rooij E, et al. Regulation of cardiac stress signaling by protein kinase d1. Mol Cell Biol. 2006;26(10):3875-3888.

33. Sauzeau V, Le Mellionec E, Bertiglio J, Scalbert E, Pacaud P, Loirand G. Human urotensin II induced contraction and arterial smooth muscle cell proliferation are mediated by RhoA and Rho kinase. Circ Res. 2001;88(11):1102-1104.

34. Inoue R, Hai L, Honda A. Pathophysiological implications of transient receptor potential channels in vascular function. Curr Opin Nephrol Hypertens. 2008;17(2):193-198.

35. Mene P. Transient receptor potential channels in the kidney: Calcium signaling, transport and beyond. J Nephrol. 2006;19(1):21-29.

36. Berra Romani R, Raqueeb A, Avelino-Cruz JE, et al. $\mathrm{Ca}^{2+}$ signaling in injured in situ endothelium of rat aorta. Cell Calcium. 2008;44(3): 298-309.

37. Berra Romani R, Mazzocco-Spezzia A, Pulina MV, Golovina VA. $\mathrm{Ca}^{2+}$ handling is altered when arterial myocytes progress from a contractile to a proliferative phenotype in culture. Am J Physiol Cell Physiol. 2008;295(3):C779-C790.
Vascular Health and Risk Management

\section{Publish your work in this journal}

Vascular Health and Risk Management is an international, peerreviewed journal of therapeutics and risk management, focusing on concise rapid reporting of clinical studies on the processes involved in the maintenance of vascular health; the monitoring, prevention and treatment of vascular disease and its sequelae; and the involvement of

\section{Dovepress}

metabolic disorders, particularly diabetes. This journal is indexed on PubMed Central and MedLine. The manuscript management system is completely online and includes a very quick and fair peer-review system, which is all easy to use. Visit http://www.dovepress.com/ testimonials.php to read real quotes from published authors. 